Journal of Southeast Asian

\title{
Book Review: Unresolved Identities: Discourse, Ambivalence, and Urban Immigrant Students by Bic Ngo
}

Gilbert Park

Ball State University, gilbertcpark@gmail.com

Follow this and additional works at: https://docs.lib.purdue.edu/jsaaea

\section{Recommended Citation}

Park, Gilbert (2010) "Book Review: Unresolved Identities: Discourse, Ambivalence, and Urban Immigrant Students by Bic Ngo," Journal of Southeast Asian American Education and Advancement: Vol. 5 : Iss. 1, Article 8.

DOI: $10.7771 / 2153-8999.1009$

Available at: https://docs.lib.purdue.edu/jsaaea/vol5/iss1/8

This document has been made available through Purdue e-Pubs, a service of the Purdue University Libraries. Please contact epubs@purdue.edu for additional information.

This is an Open Access journal. This means that it uses a funding model that does not charge readers or their institutions for access. Readers may freely read, download, copy, distribute, print, search, or link to the full texts of articles. This journal is covered under the CC BY-NC-ND license. 


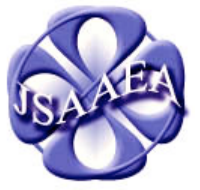

Volume 5 (2010)
Journal of Southeast Asian American

Education \& Advancement

WwW.JSAAEA.org
A peer-reviewed

scholarly journal published by the National Association for the Education \& Advancement of Cambodian, Laotian, and Vietnamese Americans (NAFEA)

Ngo, Bic. (2010). Unresolved Identities: Discourses, Ambivalence and Urban Immigrant Students. Albany, NY: SUNY Press. 146 pp. \$19.95 (Paperback). ISBN: 978-1-4384-3058-4.

\author{
Reviewed by \\ Gilbert C. Park \\ Ball State University
}

Complicating Southeast Asian Immigrant Identities in an Urban School

While the number of immigrant students from Southeast Asia in our urban schools has been on the rise over the past few decades, their school experiences have received relatively little

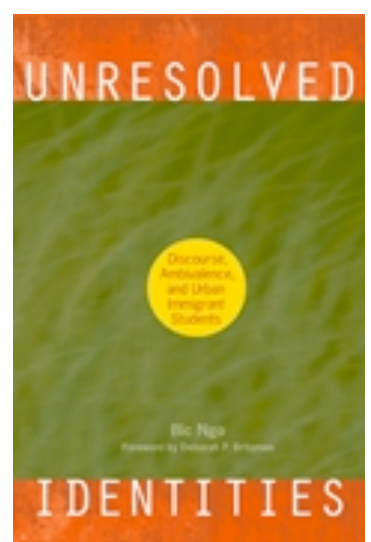
attention by educational researchers and policy makers. When discussed, the literature often highlights the difficulties as a result of the cultural differences between school, home, and ethnic community (Bankston \& Hidalgo, 2006; Souryasak \& Lee, 2007; Vang, 2005). Others explore the students' struggles to embrace or resist the pressures of assimilation (Manke \& Keller, 2006; Townsend \& Fu, 2001; Ying \& Han, 2008). Additionally, some seek to promote understanding of Southeast Asian Americans by describing their cultures (Go \& Le, 2005; Han, 2008; Yang, 2004). These works, however, seem to fall short in effectively challenging the public image of Southeast Asian American students as poor, violent and underprivileged immigrant inner-city youth of color with a heroic few overcoming cultural, economic, and social hindrances. To this end, Bic Ngo's Unresolved Identities is a timely study that illuminates the complexities and contradictions in the identities and lives of today's Southeast Asian immigrant students in an urban school.

Unresolved Identities consists of six chapters and a methodological discussion. The first chapter presents the argument in the relevant literature and the next four chapters deal with the ethnographic findings. Specifically, chapters 2 and 3 explore the discourses of urban and immigrant youth at a school she calls, Dynamic High. The next two chapters highlight the "meaning-makings" of the immigrant students' individual identities within these discourses. The final chapter includes both theoretical and practical implications of the study. These are followed by the author's positionality to the researched, descriptions of the site, data collection and analytical procedure. Overall, I found the book to be of great value to expanding the knowledge on the school experiences of Southeast Asian American students in particular and of urban

\title{
(a)
}

SOMERIGHISRESERED Readers are free to copy, display, and distribute this article, as long as the work is attributed to the author(s) and the Journal of Southeast Asian American Education \& Advancement, it is distributed for noncommercial purposes only, and no alteration or transformation is made in the work. More details of this Creative Commons license are available at http://creativecommons.org/licenses/by-nc-nd/3.0/. All other uses must be approved by the author(s) or JSAAEA. 
immigrants in general. It includes well-supported arguments, rich ethnographic findings, and meaningful educational implications for educators to better serve today's urban immigrant students.

Ngo starts the book by contextualizing the topic within the larger literature on urban and immigrant school experiences. In the process, the findings are situated to stretch our current understanding on identity and urban immigrants in general and Southeast Asian American students in particular. This is accomplished as she locates her argument within the two conflicting discourses regarding immigrant students in an urban setting. Regarding urban schools, there are images of "ghetto" schools and communities that are responsible for their own academic difficulties while, on the other hand, showcasing the resilience of a few who overcame the related challenges. Similarly, the immigrants are also reduced to the dualistic and often dichotomous positions as traditional versus Americanized or mono- versus bi-cultural. In resisting these, Ngo argues the immigrant school experiences in an urban setting are "more messier and contradictory" where their identities are beyond "binary," "multiple," "hybrid" or "situated" as discussed by other researchers (p. 3). Rather, she argues the students' understanding of themselves are complex and on-going where the "subject position of a person shifts with each speaking from one moment to the next" (p. 9).

Rich ethnographic data in the next four chapters explicates the argument. Aiming to "unsettle the hegemony of discourse that frame identities within discrete and binary categories" (p. 5), the author employs ethnographic tools like interviews and observations of Southeast Asian American students and their teachers at Dynamic High over a one academic-year period. Guided by post-structural and post-colonial frameworks, data collection and analysis focused on the moments of contradictions, uncertainty, and fractures. For instance, chapters 2 and 3 unravel the complex relationships of two seemingly contradictory discourses: the school as a war zone and the students as comeback kids.

The discourses of what Ngo calls urban dysfunction were voiced by teachers' own and others' perceptions of Dynamic High in chapter 2 with discourses such as a war zone with metal detectors, poverty, and different kind of American kids. These are consistent with the discourse that reduces an inner-city school to being a less desirable place to learn and work. While many of these terms no longer, if ever, accurately portray the school and its community because of the changes that have taken place under the leadership of previous administrators, the discourse still shaped how the teachers viewed the students and themselves. In chapter 3, we hear the teachers highlighting the resilience of some successful inner-city students. Continuing the discourse of the school and the community as a war zone, these teachers understood their students' school experiences and challenges using the framework of "culture of poverty" (as explained by Moynihan, 1965). Speaking from this perspective, some teachers portrayed the school as a safehaven for their students who came from dangerous homes and neighbors in turmoil. Put differently, the students who appreciated and took advantage of the safe-haven are positioned to succeed.

The attention shifts to the students in chapters 4 and 5 as the author examines the discourses facing the Southeast Asian American youth. One of the discourses positions Lao students as Chinese; this describes non-Southeast Asian students' ignorance of, or unwillingness to affirm, the diversity within Asian American community. The other is the resistance of the Hmong American students to accept the reductionist discourse mentioned above by affirming their own ethnicity, which in turn, created another discourse that failed to account for Lao identity. In the process, the discourse and the counter-discourse worked to further marginalize 
Lao American students. The author further complicates our understanding of identity by illuminating subjective positions of individual students' sense of selves. This is accomplished through the collisions and negotiations of multiple constructs of Lao identity of different students. This chapter is followed by in-depth analysis of three Lao American students to demonstrate the ambivalence of culture and identity via change and negotiation in chapter 5 . A student called Kett, for instance, showed both traces of the "good" student who was dedicated to school success and the "bad" student who dressed like a gangster. Another student, Vonechai, defied social boundaries as a preppy Lao girl who dressed like a middle class white person and talked like a "loud" black girl. Similarly, Chintana refused to choose between being a "good" student who did well in school and a "bad" student involved in a "gang." Instead, she chose to be as a successful school girl from the "hood."

Ngo argues in the final chapter that identities and school experiences of Southeast Asian American students must be approached and understood holistically and in individual cases. Put differently, the binary and dichotomous discourses fail to capture the multiplicity, variability and inconsistency of the students' identities. Consequently, Ngo calls for attention to the ways that "the experiences of the immigrant students in U.S. schools and society intersect with their experiences as adolescents, urban students and racial and ethnic minorities, among others" (p. 95). With this, she argues that attempts to understand the cultural differences are counterproductive since the students themselves were uncertain of who they were. Instead, Ngo calls for understanding how different identities intersect to produce moments of relative privilege and disadvantages, which include situating the selves as teachers and students in these contradictory positions. These require critical self-examinations beyond celebration of cultural others.

The ambivalence of identity as shown in these chapters exposes the limitations of notions that identities are multiple, situational, or even hybrid. Instead, identities are what she calls temporary where they can change from one moment to the next given the context. The findings are clearly linked to the discourses of larger society and the parallel representations of Dynamic High as an inner-city school and her students as troubled inner-city youth. Also, the seemingly consistent relationships between the school as a war zone and the students as war babies are complicated as the teachers stressed to represent their workplace as a decent place to work and some of their students as good students who overcame odds. Moreover, the binary framework that situated both school and the students as good or bad was challenged and expanded as Ngo reveals its limitations and implications. As a result, the author successfully "unsettle(s) what we know about urban schools and immigrant students" (p. 5). Overall, I felt that this book adds to the current literature on identity and urban education. Also, it will appeal to researchers and educators who are interested in these topics in addition to multicultural education and the school experiences of immigrants, Southeast Asians Americans, and Asian Americans in general.

\section{References}

Bankston, C. L. \& Hidalgo, D. A. (2006). Respect in Southeast Asian American children and adolescents: Cultural and contextual influences. New Directions for Child and Adolescent Development, 114, 25-38.

Go, C. G. \& Le, T. N. (2005). Gender differences in Cambodian delinquency: The role of ethnic identity, parental discipline, and peer delinquency. Crime \& Delinquency, 51(2), 220237. 
Han, W. (2008). The academic trajectories of children of immigrants and their school environments. Developmental Psychology, 44(6), 1572-1590.

Manke, M. \& Keller, K. (2007). Lao newcomers and Mennonite settlers: A case study of local cultural and language interaction. Journal of Language, Identity \& Education, 5(2), $123-$ 141.

Moynihan, D. P. (1965). The Negro family: The case for national action. Washington, DC: Brookings Institute.

Souryasak, R. \& Lee, J. S. (2007). Drawing on students' experiences, cultures and languages to develop English language writing: Perspectives from three Lao heritage middle school students. Heritage Language Journal, 5(1), 79-97.

Townsend, J. \& Fu, D. (2001). Paw's story: A Laotian refugee's lonely entry into American literacy. Journal of Adolescent and Adult Literacy, 45(2), 104-114.

Vang, C. T. (2005). Hmong-American students still face multiple challenges in public schools. Multicultural Education, 12(1), 27-54.

Yang, K. (2004). Southeast Asian American children: Not the "model minority." Future of Children, 14(2), 127-133

Ying, Y. \& Han, M. (2008). Parental contributions to Southeast Asian American adolescents' well-being. Youth \& Society, 40(2), 289-306.

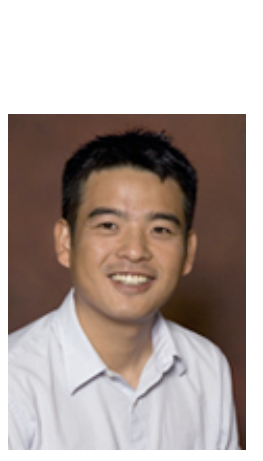

\section{About the Reviewer}

Gilbert Park is an Assistant Professor of Social Foundations and Multicultural Education at the Department of Educational Studies, The Ball State University. He graduated from University of Wisconsin-Madison and his areas of interests are in the issues regarding school experiences of students of color with a focus on Asian Americans, potential of multicultural education as a tool for advancing social justice, the Americanization process of immigrants, and the role of schooling in these areas. 


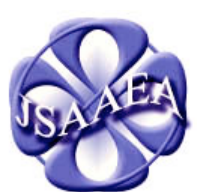

Volume 5 (2010)

\section{Journal of Southeast Asian American Education \& Advancement}

WWW.JSAAEA.org
A peer-reviewed scholarly journal published by the National Association for the Education \& Advancement of Cambodian, Laotian, and Vietnamese Americans (NAFEA)

\author{
Editor \\ Dr. Wayne E. Wright \\ University of Texas, San Antonio \\ Associate Editors \\ Dr. Chhany Sak-Humphry \\ University of Hawaii \\ Dr. KimOanh Nguyen-Lam \\ California State University, Long Beach \\ Book Review Editor \\ Dr. Vichet Chhuon \\ University of Minnesota \\ Creative Works Editor \\ Bryan Thao Worra \\ Lao Assistance Center \\ Special Advisor \\ Gregory Green \\ Curator, Echols Collection on Southeast Asia, Cornell University Library \\ Journal Manager \\ Sovicheth Boun \\ University of Texas, San Antonio
}

Comments and questions for the editorial staff may be directed to jsaaea@lists.sis.utsa.edu

\title{
Editorial Review Board
}

Dr. Carl L. Bankston III

Tulane University

Dr. Phala Chea

Lowell Public Schools

Dr. Loan Dao

Cancer Prevention Institute of California

Dr. Sophal Ear

U.S. Naval Postgraduate School

Dr. Samlong Inthaly

Minneapolis Public Schools

Dr. Kevin K. Kumashiro

University of Illinois, Chicago
Dr. Pollie Bith-Melander Asian and Pacific Islander Wellness Center

Dr. George Chigas

University of Massachusetts, Lowell

Dr. Changming Duan

University of Missouri, Kansas City

Dr. Nancy H. Hornberger

University of Pennsylvania

Dr. Peter Nien-Chu Kiang

University of Massachusetts, Boston

Dr. Stacey Lee

University of Wisconsin, Madison 


Dr. David Chanpannha Ley
Montgomery County Public Schools
Dr. Bic Ngo
University of Minnesota
Dr. Leakhena Nou
California State University, Long Beach
Dr. Mark Pfeifer
Texas A\&M University, Corpus Christi
Dr. Bounlieng Phommasouvanh
Minnesota Department of Education
Dr. Kalyani Rai
University of Wisconsin, Milwaukee
Dr. Nancy J. Smith-Hefner
Boston University
Dr. Loan Tran
Center for Applied Linguistics
University of California, Berkeley
Dr. Terrence G. Wiley

\author{
Dr. Sue Needham \\ California State University, Dominguez Hills \\ Dr. Max Niedzwiecki \\ Daylight Consulting Group \\ Dr. Clara Park \\ California State University, Northridge \\ Dr. Loan T. Phan \\ University of New Hampshire \\ Dr. Karen Quintiliani \\ California State University, Long Beach \\ Dr. Fay Shin \\ California State University, Long Beach \\ Dr. Yer J. Thao \\ Portland State University \\ Dr. Myluong Tran \\ San Diego State University \\ Dr. Linda Trinh Vo \\ University of California, Irvine \\ Dr. Zha Blong Xiong \\ University of Minnesota
}

Dr. Kou Yang

California State University, Stanislaus

\section{Doctoral Student Editorial Review Board}

\author{
Keo Chea-Young \\ University of Pennsylvania \\ Peter Tan Keo \\ Columbia University \\ Ha Lam \\ Arizona State University \\ Monirith Ly \\ Texas State University-San Marcos \\ Malaphone Phommasa \\ University of California, Santa Barbara \\ Rassamichanh Souryasack \\ University of California, Santa Barbara \\ Layheng Ting \\ State University of New York, Albany \\ Tinou Tran \\ University of Houston, Texas \\ Phitsamay Sychitkokhong Uy \\ Harvard University
}

Annie BichLoan Duong

San Joaquin County Office of Education

Polinda Keo

University at Albany, SUNY

Ravy Lao

University of California, Santa Barbara

Giang Pham

University of Minnesota

Vanna Som

Harvard University

Somongkol Teng

University of Minnesota

\author{
Alisia Tran \\ University of Minnesota \\ Silvy Un \\ University of Minnesota \\ Yang Sao Xiong \\ University of California, Los Angeles
}

